\section{MRS Board seeks voters' approval to changes in governance documents}

\author{
www.mrs.org/elections
}

I $\mathrm{n}$ conjunction with the annual election of the Materials Research Society this year, the Board of Directors will seek member approval of changes to two governance documents - the Articles of Incorporation, and the document currently entitled MRS Constitution.

Changes to the Articles of Incorporation have been recommended by independent legal counsel and are "housekeeping" items in nature, that is, correcting the address of MRS Headquarters and removing redundant text describing the purpose of the organization, which is contained elsewhere.
Non-profit law in the Commonwealth of Pennsylvania, where MRS is incorporated, does not acknowledge the term "Constitution," but refers to the governing documents of non-profit organizations as "Bylaws." Legal counsel recommended to MRS that it streamline the language in the current MRS Constitution and also rename it "Bylaws." Beth Stadler, MRS Secretary during that period, worked with the attorneys to prepare appropriate changes to the document. All essential information contained in the present Constitution has been retained in the proposed "Bylaws." All items in the current constitution which are membervoted will remain so in the new Bylaws, and any issue that is currently Boardvoted will remain so, but now as a policy described within a new separate document entitled the MRS Policy Manual.

As noted in Jim De Yoreo's President's Letter in the April 2011 issue of MRS Bulletin, “. . . these changes in no way alter the privileges or rights of MRS members."

Following is a full descrip-

$M R S$ tion of the proposed changes to be enacted when the "Constitution" is replaced by the "Bylaws." Also included is the proposed final, full text of the proposed Articles of Incorporation and the new Bylaws.

The MRS Board of Directors believes that the new proposed Bylaws are clearer and simpler than the current Constitution/Bylaws, so that they will be easier to read and understand.

Sean J. Hearne MRS Secretary

Article I - Name and Objective

1. The name of this organization shall be the Materials Research Society (the "Society")

Clarifies that when the term "the Society" is used in the rest of the document, it refers to $M R S$.

2. The objective of this Society is to serve professionals working in the field of materials science and engineering by: (a) fostering interaction among materials scientists and engineers; (b) promoting an interdisciplinary approach to materials research and engineering; (c) sponsoring interdisciplinary meetings of interest to Members; and (d) disseminating information relevant to the materials community.

No change.

3. The Society shall not engage in any activity inconsistent with: (a) its Articles of Incorporation, as amended; (b) the provisions for not-forprofit status in Section 501(c)(3) of the Internal Revenue Code of the United States; (c) the Pennsylvania Nonprofit Corporation Law of 1988, as it may be amended from time to time; and (d) other applicable law.

Emphasizes need to stay self-consistent with the Articles of Incorporation and other legal documents.
1. The name of this organization shall be the Materials Research Society.
3. The Society shall not engage in any activity inconsistent with: (a) the provisions for not-for-profit status in Section 501(c)(3) of the Internal Revenue Code of the United States; (b) the Pennsylvania Nonprofit Corporation Law of 1988, as it may be amended from time to time; and (c) other applicable law. 


\section{Article II - Membership}

1. Membership in the Society shall be open to all persons interested in materials research and engineering.

No Change.

2. The Board of Directors shall establish categories of membership and the benefits, responsibilities, and fees for such membership categories as it deems to be reasonable and in the best interests of the Society.

No Change

\section{Article III - Governance of the Society}

Some information contained in current Articles III and IV has been rearranged and

streamlined as appropriate in the new Bylaws to improve the logic flow.

1. The governance of the Society shall be the responsibility of the Board of Directors.

No Change.

2. The Board of Directors shall be composed of (a) the Officers of the Society, and (b) 12 to 21 directors, of which up to $25 \%$ of them may be appointed. The exact number shall be set by resolution of the Board of Directors. The Directors who are appointed by the Board pursuant to this Section or Section 4 of this Article need not be Members; all other Directors shall be elected by the Members from among the Members. (Vacancies, incapacities, or other inability to serve in an officer or director position shall be filled by appointment by the Board of Directors, for the remainder of the term or until the next annual election, at the discretion of the Board. Such appointments shall not be counted in the $25 \%$ appointment limit.) Elected Directors shall serve a three-year term, and may not serve more than two sequential three-year terms, and appointed Directors shall serve up to a three-year term. The Board of Directors may, at its discretion, propose nomination of Directors for election to terms of less than three years in order to ensure that approximately one-third of the Directors are elected annually.

Sets clear guidelines for a minimum number of Directors and raises the potential maximum number

3. The Officers of the Society shall be a President, a Vice President (who is also the president-elect), a Secretary, a Treasurer, and the Immediate Past President.The Vice President shall serve sequential one-year terms as Vice President, President, and Immediate Past President; the Secretary shall serve a three-year term; the Treasurer shall be appointed by the Board for an initial one-year term, and may serve two additional years with Board approval. (Each Officer of the Society shall be an MRS Member).
2. The Board of Directors shall be composed of the Officers of the Society and up to 18 Directors.

3. The Officers of the Society shall be a President, a Vice President (who is also the president-elect), a Secretary, a Treasurer, and the Immediate Past President. 
4. A vacancy, incapacity, resignation or any other inability to serve in any Officer or Director position shall be filled by appointment by the Board of Directors, for the remainder of the term or until the next election, at the discretion of the Board; provided, however, in the event of the death or incapacity of the President as declared by the Board of Directors, the Vice President shall immediately become President and complete the term of the predecessor as well as the presidential term to which the Vice President was elected to serve.
(Current ARTICLE III, Sections 7, 10)
5. The Board of Directors may organize itself internally as it deems appropriate to govern the Society effectively. Board structure and policies shall be described in written documents readily accessible to Members.
4. The Board of Directors may organize itself internally as it deems appropriate to govern the Society effectively. Board structure and policies shall be described in written documents readily accessible to Members. (NEW ARTICLE III, Section 5)
6. The Board of Directors shall meet at least twice a year, at times and locations determined by the Board or as called by the President.
5. The Board of Directors, by bylaws or Board resolution, may designate a subset of the Board authorized to act on behalf of the Board under conditions prescribed in such stated bylaws or resolutions. (MOVED TO POLICY MANUAL: 2.1.2 Board Structure)
7. A quorum for a meeting of the Board of Directors shall be $50 \%$ of the Board including the President or Vice President. When a quorum is present, action of the Board shall be valid and effective with the affirmative vote of a majority of the Directors present, unless otherwise stated in these Bylaws.
6. The President shall be the Chair of the Board of Directors, generally act as the representative of the Society, and perform other duties as established by the Board of Directors. (MOVED TO POLICY MANUAL: 2.1.1 Officer Roles)
8. The Board of Directors may initiate amendments to the Bylaws of the Society and shall submit such amendments to the Members within 120 days for a vote by ballot procedures prescribed by the Board. A two-thirds $(2 / 3)$ vote of a minimum of $5 \%$ of all Members entitled to vote thereon shall be required to enact the amendments. If a minimum of $5 \%$ of all Members entitled to vote do not participate in the vote, the requested amendments shall fail.

Stipulates the necessary size of the voting quorum for adoption of a Board-initiated amendment, as per legal counsel.

9. Members of the Society shall be notified in a timely fashion of passed changes to the Bylaws or the Articles of Incorporation of the Society. Such changes to the existing Bylaws or Articles of Incorporation shall become effective immediately unless stipulated differently in the resolution adopting such measures.

10. An Officer or Director may be removed from office by a two-thirds $(2 / 3)$ vote of the Board of Directors.
7. The Vice President shall act for the President on any occasion when the latter is unable to carry on normal duties, when requested by the President, or as approved by the Board of Directors. (MOVED TO POLICY MANUAL: 2.1.1 Officer Roles) In the event of the death or incapacity of the President as declared by the Board of Directors, the Vice President shall immediately become President and complete the term of the predecessor as well as the presidential term to which the Vice President was elected to serve. (NEW ARTICLE III, Section 4)

8. The Secretary shall oversee the maintenance of the records of the Society. (MOVED TO POLICY MANUAL: 2.1.1 Officer Roles) 


\begin{tabular}{|c|c|}
\hline & $\begin{array}{l}\text { 10. A vacancy, incapacity, or any other inability } \\
\text { to serve in any Officer or Director position shall } \\
\text { be filled by appointment by the Board of Direc- } \\
\text { tors, for the remainder of the term or until the next } \\
\text { annual election, at the discretion of the Board. } \\
\text { (NEW ARTICLE III Section 4, and POLICY } \\
\text { MANUAL: 2.1.1 Officer Roles) }\end{array}$ \\
\hline & $\begin{array}{l}\text { 11. The Board of Directors shall meet at least twice } \\
\text { a year, at times and locations determined by the } \\
\text { Board or as called by the President. (NEW AR- } \\
\text { TICLE III, Section } 6 \text { and POLICY MANUAL } \\
\text { 2.1.2 Board Structure) }\end{array}$ \\
\hline & $\begin{array}{l}\text { 12. A quorum for a meeting of the Board of Di- } \\
\text { rectors shall be } 50 \% \text { of the Board including the } \\
\text { President or Vice President. When a quorum is } \\
\text { present, action of the Board shall be valid and } \\
\text { effective with the affirmative vote of a majority } \\
\text { of the Directors present. (NEW ARTICLE III, } \\
\text { Section } 7 \text { and POLICY MANUAL 2.1.2 Board } \\
\text { Structure) }\end{array}$ \\
\hline & $\begin{array}{l}\text { 13. The Board of Directors may enact or amend, } \\
\text { by a majority vote, bylaws and policies to govern } \\
\text { the Society. (MOVED TO POLICY MANUAL: } \\
\text { 2.1.2 Board Structure) }\end{array}$ \\
\hline & $\begin{array}{l}\text { 14. Members of the Society shall be notified in a } \\
\text { timely fashion of changes to bylaws or policies } \\
\text { governing the affairs of the Society. Such bylaws, } \\
\text { policies, or changes to existing bylaws or policies } \\
\text { shall become effective immediately unless stipu- } \\
\text { lated differently in the resolution adopting such } \\
\text { measures. (NEW ARTICLE III, Section 9) }\end{array}$ \\
\hline & $\begin{array}{l}\text { 15. An Officer or Director may be removed from } \\
\text { office by a two-thirds majority vote of the Board of } \\
\text { Directors. (NEW ARTICLE III, Section 10) }\end{array}$ \\
\hline $\begin{array}{l}\text { Article IV - Member Voting Rights } \\
\text { Some information contained in current Articles III and } \\
\text { streamlined as appropriate in the new Bylaws to }\end{array}$ & $\begin{array}{l}\text { lections } \\
\text { been rearranged and } \\
\text { e the logic flow. }\end{array}$ \\
\hline $\begin{array}{l}\text { 1. Members are entitled to vote by annual ballot for (a) the Directors } \\
\text { (not including any Directors appointed by the Board in accordance } \\
\text { with Article III, Section } 2 \text { of these Bylaws); (b) the Vice President; } \\
\text { (c) and a Secretary, when applicable. The candidates for these positions are } \\
\text { to be from among the Members. In an election of Directors and Officers, } \\
\text { the candidates receiving the highest number of votes shall be elected. }\end{array}$ & $\begin{array}{l}\text { 1. Members are entitled to vote: (a) for Directors; } \\
\text { (b) for the Vice President and Secretary; (c) on } \\
\text { amendments to the Constitution; (d) on Member- } \\
\text { initiated referendums related to bylaws adopted } \\
\text { or changed by the Board of Directors; and (e) on } \\
\text { proposals submitted by Members to remove Of- } \\
\text { ficers or Directors. (NEW ARTICLE IV, Sec- } \\
\text { tions } 1 \text { and 2) }\end{array}$ \\
\hline
\end{tabular}


2. Members are also entitled to vote on (a) Board- or Member-initiated amendments to the Bylaws; and (b) Member-initiated proposals to remove Officers or Directors. A majority of a minimum of 5\% of all Members entitled to vote thereon shall be required to enact a Board-initiated amendment. Proposals to amend the Bylaws may be included on the annual ballot.

Stipulates the necessary size of the voting quorum for adoption of a Board-initiated amendment, as per legal counsel.

3. The annual election of Officers and Directors, any vote to amend the Bylaws, or any vote to remove an Officer or Director of the Society may be held by ballot, mail or electronic transmission, and need not be held at a physical meeting of the Members. The annual election shall constitute the annual meeting of the Members.

To comply with Pennsylvania non-profit law: The annual election shall constitute the annual meeting of the Members.

4. With respect to all matters upon which Members are entitled to vote, every Member in good standing 30 days prior to the submission of a ballot is entitled to one vote. Members in "good standing" are those listed as "active" in the Society database by virtue of being current on dues or by having attended an MRS meeting within the preceding 12 months, if membership status was included with the registration fee.
2. An election shall be held annually to elect a Vice President, Directors, and, when applicable, a Secretary, and this annual election may be by ballot, mail or electronic transmission, and need not be held at a meeting of the Members. Proposals to change the Constitution may be included on the annual ballot. (NEW ARTICLE IV, Sections 1, 2, 3)

Defines the term "good standing".

5. A petition signed by at least $5 \%$ of the Members can be made to the Board of Directors to request a Member-initiated amendment to the Bylaws. Any such properly requested amendment shall be submitted within 120 days to the Members by ballot procedures prescribed by the Board. A two-thirds (2/3) vote of a minimum of $10 \%$ of all Members entitled to vote thereon shall be required to enact an amendment requested by the Members. If a minimum of $10 \%$ of all Members entitled to vote do not participate in the vote, the requested amendment shall fail.

Stipulates the necessary size of the voting quorum for adoption of a Member-initiated amendment, as per legal counsel.

6. Removal of an Officer or Director may be proposed to the Board of Directors by a petition signed by at least $5 \%$ of the Members. The Board of Directors shall indicate whether it approves or disapproves, but in either case the proposed removal shall be submitted within 120 days to the Members for a vote by ballot procedures prescribed by the Board. A two-thirds (2/3) vote of a minimum of $10 \%$ of all Members entitled to vote thereon shall be required to enact the removal. If a minimum of $10 \%$ of all Members entitled to vote do not participate in the vote, the requested removal shall fail.
3. With respect to all matters upon which Members are entitled to vote, every Member is entitled to one vote, and any such vote may be by ballot, mail or electronic transmission. Members in good standing 30 days prior to the submission of any such ballot to the Members shall be eligible to vote. (NEW ARTICLE IV, Sections 3 and 4)
4. Whenever any action is to be taken by vote of the Members, it shall be authorized by a majority of the votes cast. (CHANGED AND MOVED TO ARTICLE IV, Sections 2 and 5) In an election of Directors, the candidates receiving the highest number of votes shall be elected. (ARTICLE IV, Section 1)
5. Fifteen Directors shall be elected by the Members from among the Members for terms that are normally three years. The Board of Directors may, at its discretion, propose nomination of Directors for election to terms of less than three years in order to ensure that approximately one-third of the Directors are elected annually. The Board of Directors may appoint as Directors up to three persons for threeyear terms. Directors may serve not more than two sequential three-year terms. (CHANGED: 75\% must be elected; ARTICLE III, Section 2)

6. The Vice President shall be elected annually by the Members from among the Members and shall serve sequential one-year terms as Vice President, President, and Immediate Past President. (ARTICLE III, Section 3) 


\begin{tabular}{|c|c|}
\hline & $\begin{array}{l}\text { 7. The Secretary shall be elected by the Members } \\
\text { from among the Members for a three-year term. } \\
\text { (ARTICLE III, Section 3) }\end{array}$ \\
\hline & $\begin{array}{l}\text { 8. Removal of an Officer or Director may be pro- } \\
\text { posed in writing to the Board of Directors by any } \\
100 \text { Members. The Board of Directors shall in- } \\
\text { dicate whether it approves or disapproves, but in } \\
\text { either case the proposed removal shall be submit- } \\
\text { ted to the Members for a vote in a timely fashion. } \\
\text { A two-thirds majority of Members voting must } \\
\text { vote in favor of removal. (CHANGED: 5\% of } \\
\text { membership and 10\% quorum; ARTICLE IV, } \\
\text { Section 6) }\end{array}$ \\
\hline & $\begin{array}{l}\text { 9. Any } 100 \text { Members may petition the Board of } \\
\text { Directors for a referendum on any bylaws adoption } \\
\text { or change; any such referendum shall be submit- } \\
\text { ted in a timely fashion to the Members by ballot } \\
\text { procedures prescribed by the Board, and must } \\
\text { be approved by two-thirds of Members voting. } \\
\text { (ARTICLE IV, Sections } 2 \text { and 5) }\end{array}$ \\
\hline \multicolumn{2}{|c|}{ Article V - Activities of the Society } \\
\hline & $\begin{array}{l}\text { 1. The Society shall conduct activities that, in } \\
\text { the reasonable judgment of the Board of Direc- } \\
\text { tors, contribute to the best interests of the Mem- } \\
\text { bers. (REMOVED PER ADVICE OF LEGAL } \\
\text { COUNSEL) } \\
\text { Legal counsel advised that "Article V, Section I" } \\
\text { be removed because it could be deemed to conflict } \\
\text { with the requirements under U.S. Federal guidelines } \\
\text { [IRS Section } 501(\mathrm{c})(3)] \text { that MRS operate exclu- } \\
\text { sively for charitable, educational and scientific } \\
\text { research purposes, rather than in the best interests } \\
\text { of individuals. }\end{array}$ \\
\hline $\begin{array}{l}\text { 1. The Board of Directors may establish activity units to accomplish } \\
\text { the mission and goals of the Society, including standing committees, } \\
\text { subcommittees, task forces, local Sections, student chapters, affiliated } \\
\text { organizations and editorial boards for print or electronic publications. } \\
\text { The methods and authority for designating such activity units, the means } \\
\text { for appointing the chair and members, and the responsibilities, duties, } \\
\text { powers, limitations, procedures and other attributes of structure or pro- } \\
\text { cess shall be prescribed by the Board through policies or other written } \\
\text { charges from the Board. Unless the Board determines that confidentiality } \\
\text { should be maintained, the charge, responsibilities, powers, limitations, } \\
\text { processes, and membership of activity units shall be described in printed } \\
\text { or electronic descriptions readily accessible by Members. No subsidiary } \\
\text { unit or any officer or member thereof may act as an agent for the Society, } \\
\text { except as specifically authorized in writing by a person so empowered } \\
\text { by the Board of Directors. }\end{array}$ & $\begin{array}{l}\text { 2. The Board of Directors may establish subsidiary } \\
\text { units (such as local Sections, student chapters, and } \\
\text { affiliated organizations) to advance the interests of } \\
\text { the Society. Such units shall be governed by by- } \\
\text { laws or policies established by the Board of Direc- } \\
\text { tors. No subsidiary unit or any officer or member } \\
\text { thereof may act as an agent for the Society, except } \\
\text { as specifically authorized in writing by a person so } \\
\text { empowered by the Board of Directors. (ARTICLE } \\
\text { V, Section 1) }\end{array}$ \\
\hline
\end{tabular}


2. Any committee, subcommittee or other activity unit established by the Board of Directors may be authorized to act on behalf of the Board with such power and authority as prescribed in such policies or other written charges from the Board; provided, however, no committee, subcommittee or other activity unit shall have the power or authority to: (a) Submit to Members any action requiring approval of Members under these Bylaws or applicable law; (b) Fill vacancies on the Board of Directors; (c) Adopt, amend or repeal Bylaws; (d) Amend or repeal any action of the Board of Directors; or (e) Act on matters committed by the Bylaws or action of the Board of Directors to another committee.

Article $V$, Section 2 is added per advice of legal counsel to clarify that certain activities can only be handled by the governing body of the Society, the Board of Directors.
3. The Board of Directors may establish activity units to accomplish the mission and goals of the Society, including standing committees, subcommittees, task forces, and editorial boards for print or electronic publications. The methods and authority for designating such activity units, the means for appointing the chair and members, and the responsibilities, duties, powers, limitations, procedures and other attributes of structure or process shall be prescribed by the Board through bylaws, policies, or other written charges from the Board. Unless the Board determines that confidentiality should be maintained, the charge, responsibilities, powers, limitations, processes, and membership of activity units shall be described in printed or electronic descriptions readily accessible by Members. (ARTICLE V, Section 1)
3. The Board of Directors may hire a chief staff officer to direct the operations of the Society and to perform other functions as determined by the Board. The title, qualifications, duties, compensation, authority, and other attributes of the chief staff officer position shall be determined by the Board and may be changed at any time by the Board as it deems in the best interests of the Society. The chief staff officer shall report to and be accountable to the Board of Directors. The Board of Directors may designate the chief staff officer as an officer of the Society by whatever means, title, authority and limitation the Board deems appropriate to serve the needs and interests of the Society. The chief staff officer shall serve as a non-voting ex officio member of the Board of Directors.
4. The Board of Directors may hire a chief staff officer to direct the operations of the Society and to perform other functions as determined by the Board. The title, qualifications, duties, compensation, authority, and other attributes of the chief staff officer position shall be determined by the Board and may be changed at any time by the Board as it deems in the best interests of the Society. The chief staff officer shall report to and be accountable to the Board of Directors. The Board of Directors may designate the chief staff officer as an officer of the Society by whatever means, title, authority and limitation the Board deems appropriate to serve the needs and interests of the Society. (ARTICLE V, Section 3)

Codifying the precedent that the chief staff officer serves as an ex officio member of the Board.

\section{Article VI - Finances}

1. Financial obligations of the Society shall be approved by the Board of Directors through an annual budget and other documented Board actions, as needed, to meet the needs of the Society.
1. Financial obligations of the Society shall be approved by the Board of Directors through an annual budget and other documented Board actions, as needed, to meet the needs of the Society. The financial records of the Society shall be audited annually. (ARTICLE VI, Sections 1 and 2)

2. The financial records of the Society shall be audited annually.

2. The funds of the Society shall be deposited in the name of the Society in financial institutions designated by the Board of Directors. Checks and other documents and papers shall be signed or endorsed on behalf of the Society by persons designated by the Board of Directors. (ARTICLE VI, Section 3)

3. The funds of the Society shall be deposited in the name of the Society in financial institutions designated by the Board of Directors. Checks and other documents and papers shall be signed or endorsed on behalf of the Society by persons designated by the Board of Directors.
3. In the event of dissolution of the Society, disposition of funds shall be determined by the Board of Directors in accordance with federal and state law applicable to not-for-profit organizations chartered under Section 501(c)(3) of the Internal Revenue Code. (REMOVED; CONTAINED IN THE ARTICLES OF INCORPORATION) 


\section{Article VII - Personal Liability of Directors, Officers and Members}

1. To the fullest extent that the laws of the Commonwealth of Pennsylvania, as now in effect or as hereafter amended, permit elimination or limitation of the liability of directors and officers, no Director or Officer of the Society shall be personally liable for damages for any action taken, or any failure to take action, as a Director or Officer, nor shall the Officers, Board of Directors, staff, and Members be personally liable for the debts, liabilities, or obligations of the Society.
4. The Officers, Board of Directors, staff, and Members shall not be personally liable for the debts, liabilities, or obligations of the Materials Research Society. (Added to ARTICLE VII, Section 1)
2. The Board of Directors may adopt policies and procedures governing the indemnification of persons against claims arising out of service to the Society or a related entity. In the absence of Board-adopted indemnification policies and procedures, the applicable default provisions of the Pennsylvania Nonprofit Corporation Law shall apply.
1. To the fullest extent that the laws of the Commonwealth of Pennsylvania, as now in effect or as hereafter amended, permit elimination or limitation of the liability of directors and officers, no Director or Officer of the Society shall be personally liable for damages for any action taken, or any failure to take action, as a Director or Officer.

\section{Article VIII - Amendments}

2. The Board of Directors, by bylaws, may adopt policies and procedures governing the indemnification of persons against claims arising out of service to the Society or a related entity. In the absence of Board-adopted indemnification policies and procedures, the applicable default provisions of the Pennsylvania Nonprofit Corporation Law shall apply. (Removed the words "by Bylaws" because the new Bylaws would require membership vote.)

\begin{tabular}{|l|l|}
\hline \multicolumn{1}{|l|}{$\begin{array}{l}\text { 1. Amendments to the Constitution may be proposed } \\
\text { by the Board of Directors. In addition, amendments } \\
\text { may be proposed in writing to the Board of Direc- } \\
\text { tors by any 100 Members. The Board of Directors } \\
\text { shall indicate whether it approves or disapproves, } \\
\text { but in either case all amendments shall be submitted } \\
\text { to the Members for ratification in a timely fashion. } \\
\text { (ARTICLE III, Section 8 and ARTICLE IV, Sec- } \\
\text { tions 2, 5) }\end{array}$} \\
$\begin{array}{ll}\text { 2. Proposed amendments to the Constitution shall be } \\
\text { submitted to the Members for ratification, electroni- } \\
\text { cally, by mail ballot, or by other means approved by } \\
\text { the Board of Directors. Members in good standing } \\
\text { 30 days prior to the submission of the ballots to the } \\
\text { Members shall be eligible to vote. An amendment is } \\
\text { accepted if approved by two-thirds of those Mem- } \\
\text { bers voting on it, and takes effect immediately or as } \\
\text { stipulated in the amendment proposal. (ARTICLE } \\
\text { IV, Sections 2, 4, 5) }\end{array}$ \\
\end{tabular}

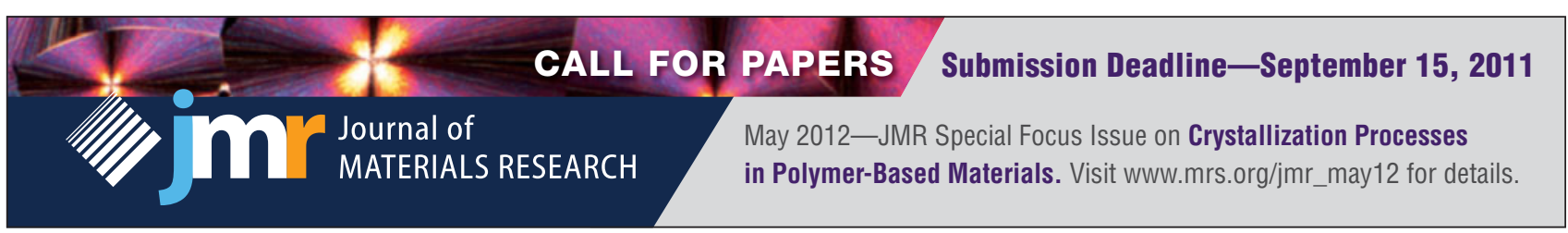

